\title{
High Performance Work Systems in the Service Sector: A Literature Review
}

\author{
N. W. K. D. K. Dayarathna \\ Senior Lecturer \\ Faculty of Management Studies and Commerce \\ University of Sri Jayewardenepura \\ dushar@sjp.ac.lk
}

Cite this article: Dayarathna, N.W.K.D.K. (2018), High Performance Work Systems in the Service Sector:A Literature Review, Sri Lankan Journal of Human Resource Management, Vol. 8, No. 1, pp. 52-59. 


\begin{abstract}
Over the past few years, there has been growing research interest in the competitive advantage associated with high performance work systems. There is rising interest in using high performance work system practices, because evidence showed that organizations that implemented such systems recorded remarkable success, especially in organizations in the manufacturing industry. It will be interesting to find out whether the impressive results can be applied to service sector since work culture and management practices differ between the manufacturing firms and service firms. This conceptual paper explores the research findings of high performance work systems in the service sector. The paper may be valuable to those who are interested in understanding the phenomenon of high performance work systems in the service sector for research purposes.
\end{abstract}

Key Words: High Performance Work Systems, Human Resource Management, Organizational Performance, Service Sector

\title{
Introduction
}

People are our most important asset and the human resource management (HRM) literature highlights the importance of people in achieving organizational performance (OP). Studies in manufacturing and service industries show that management systems that encourage commitment and competence of people achieve greater productivity, quality and cost efficiency (Pfeffer, 1998). Based on research evidence to date, it is clear that high performance work systems (HPWS) are one of the important components that can help an organization to achieve greater performance (Dayarathna, 2012; Guthrie, Flood, Liu, and MacCurtain, 2009; Iddhagoda and Opatha, 2018).

High performance work systems, a type of HRM system, are an important concept in contemporary research on business organizations (Boxall and Macky, 2007; Dayarathna, 2012). The concept of HPWS mainly focuses on employee involvement and organizational commitment and it (the concept of HPWS) first originated in the United States (Boxall, 2012; Boxall and Macky, 2009). As stated by Boxall and Macky (2009), three landmark publications paved the way to concern the importance of HPWS in America: (1) America's Choice: High Skills or Low Wages! Published by Commission on the Skills of the American Workforce in 1990, (2) the new American Workplace published by Appelbaum and Batt in 1994 and (3) Manufacturing Advantage published by Appelbaum, Bailey, Berg, and Kalleberg in 2000. In the 1970 s and 1980s, with the rise of Japanese high-quality production systems, U.S. firms found that their HRM systems did not fit with their competitive context (Boxall and Macky, 2007). Faced with global competition, U.S. companies needed to better utilize their human resources (HR) as they strived to improve quality and productivity to compete with firms like Toyota (Dessler, 2009). They gave a new life to their HRM systems by introducing HPWS which increased the involvement of employees and raised their skills and incentives (Macduffie, 1995). 
Logically, the concept of HPWS claims that there exists a system of HRM practices that leads in some way to superior OP (Boxall and Macky, 2009). As stated by Leana and Van Buren (1999), HPWS help to enhance trust in management and also organization's social capital. From Boxall and Purcell (2008) point of view, an HPWS affects performance on multiple levels.

On one level it affects individual performance. Every high performance work system works through its impacts on the skills and knowledge of individual employees, their willingness to exert effort and their opportunities to express their talents in their work.... HPWS also affect a range of variables on a more collective level, helping to build organizational capabilities, influencing the organizational culture, and social and psychological climate in which individuals are embedded (Boxall and Macky, 2009: 7).

A large body of HPWS research suggests that the use of HPWS enhances employees' competencies, motivation and performance. It is associated with lower employee turnover rates and higher satisfaction (e.g., Huselid, 1995; Kuvaas and Dysvik, 2010; McAlearney, Garman, Song, McHugh, Robbins, and Harrison, 2011; Zatzick and Iverson, 2011), employee commitment (e.g., Kuvaas and Dysvik, 2010), higher labour productivity (e.g., Datta, Guthrie, and Wright, 2005; Huselid, 1995), lower injury rates and better safety performance (e.g., Zacharatos, Barling, and Iverson, 2005), lower rate of burnout associated with emotional labour(e.g., Bartram, Casimir, Djurkovic, Leggat, and Stanton, 2012; Macky and Boxall, 2007) and better OP (e.g., Bartram, Stanton, Leggat, Casimir, and Fraser, 2007; Becker and Huselid, 2006; Guthrie et al., 2009; Huselid, 1995; Mcclean and Collins, 2011; Nikandrou and Papalexandris, 2007; O'neill, Feldman, Vandenberg, Dejoy, and Wilson, 2011).

\section{Purpose Statement}

This conceptual paper is intended to identify and understand the applicability of HPWS to the service sector organizations. Therefore, the inquiry question for this paper is: Are HPWS applicable to the service sector organizations? The answer to the inquiry question was based on an extended review and analysis of literature.

\section{Methods for Collecting Literature}

This conceptual paper is based solely on a review and analysis of research from the literature. Since the topic deals with HPWS, the method for collecting literature was using HRM databases. The most helpful databases were ABI/INFORM Complete (ProQuest), Business Source Complete (EBSCO), Emerald Insight, ProQuest Business, Sage Journals Online, Science Direct (Elsevier), and Wiley Online Library, where a number of articles were deemed useful for the topic of HPWS in the service sector.

\section{Findings from Literature}

It is commonly argued that HPWS are less effective in the service sector. As Harley, Allen, and Sargent (2007:610) report: 
The theoretical arguments made against the general applicability of HPWS in the service sector are based on the segmentation of employment in services. The logic of the argument is that markets for services are very clearly divided into low-value and high-value segments with the result that employment in service organizations is correspondingly segmented.

According to their argument, in the low-value/low-skill segments of the sector (where work can be standardized to deliver a standard product), work will be characterized by Taylorist or neo-Taylorist practices. While in the high-value/ high-skill segments, employees may enjoy more humanistic HRM practices. However, some researchers believe that the HPWS practices are applicable to both high-skilled service workers (e.g., Bartel, 2004) and lowskilled workers (e.g., Berg and Frost, 2005). But the findings of these two studies are questionable since neither of these two studies includes both groups of employees. As Harley et al. (2007) state, it is not possible to compare low- and high-skilled employees while keeping other factors constant.

In spite of a growing body of empirical research on HPWS, there is little evidence on their application in the service sector. According to Berg and Frost (2005), low-skilled service employees reap few benefits from HPWS because their jobs are so poorly paid, physically demanding and lacking in intrinsic reward. However, Berg and Frost (2005) do not assess the relative impact of HPWS on different groups of employees (high- and low-skilled employees). Most interestingly Harley et al. (2007) suggest that HPWS practices are applicable to both low-skilled employees and high-skilled employees. These findings challenge the theoretical argument that HPWS are only applicable to high-skilled workers and have very limited applicability in the service-sector organizations. Their findings highlight the assumption that when applied to both low- and high-skilled employees, HPWS will have more positive effects on the high-skilled employees than the low-skilled employees.

There are also studies on HPWS in the service sector that HPWS fit with the nature of the industry or the competitive segment within the industry (Boxall and Macky, 2007). According to Boxall and Macky (2007:265-266), "HPWS are necessary in professional services because employees capable of providing professional services need to be paid well and developed continuously, but they are also becoming important in those service industries which are able to segment customer need." They argue that if the employees are satisfied and qualified enough they can satisfy customer needs. For example, luxury hotels can improve revenue and customer relation through HPWS that empower employees and invest in the employee development and ultimately that will support high quality customer service. However, HPWS are unlikely in mass services where customers are price conscious (in mass services, prices are kept low through low-skilled work and through labour serving technology and customer self-service. In the professional service, organizations compete through esoteric knowledge) (Boxall and Macky, 2007). As noted by Batt (2007: 443), "Segmentation strategies make two important assumptions: that there is necessary tradeoffs between cost and quality and that demand in the mass market is driven primarily by price, and hence, investing in HPWS doesn't pay off". However, according to Pine (1993), 
there is evidence that competing on quality and investing in HPWS can pay off in priceconscious markets too. A number of case studies of low-wage service work in hospitals, hotels, banking, and telecommunications showed that investing in HPWS practices could pay off in these markets (Appelbaum, Bernhardt, and Murnane, 2003).

Some researchers argue that HPWS practices are likely to be more effective in manufacturing organizations than in services (Appelbaum et al., 2000). As per Harley et al. (2007), this may reflect the fact that the majority of the influential studies on HPWS have been conducted in manufacturing sector. Although limited, there is a body of research which suggests that HPWS are successful in the service sector too (Boxall and Macky, 2007) and that they are associated with positive employee outcomes (e.g., Chuang and Liao, 2010; Harley et al., 2007; Kuvaas, 2008; Kuvaas and Dysvik, 2010; Leggat, Bartram, and Stanton, 2011; Liao, Toya, Lepak, and Hong, 2009; McAlearney, Garman, Song, McHugh, Robbins, and Harrison, 2011; Messersmith, Patel, and Lepak, 2011; Preuss, 2003). McAlearney, Garman, Song, McHugh, Robbins, and Harrison's (2011) study reported the links between HPWS and employee outcomes (e.g., turnover, higher satisfaction) in health care organizations in USA. Preuss's (2003) study in 50 acute-care units in 13 hospitals in USA is also similar to that of McAlearney, Garman, Song, McHugh, Robbins, and Harrison's (2011) study. The author explored the relationship among HPWS, information quality, and performance quality. HPWS improve performance quality and overall, the researcher found that information quality is an important factor linking HPWS and OP quality. Messersmith, Patel, and Lepak's (2011) research in the service departments from 16 local government authorities in Wales also confirm the positive outcomes associated to HPWS in the service sector. The results show that department level HPWS utilization is associated with enhanced levels of job satisfaction, organizational commitment, and psychological empowerment. In turn, these attitudinal variables were found to be positively linked to enhanced organizational citizenship behaviours, which are further related to departmental performance.

\section{Conclusion}

As a conclusive note, we should be very careful about accepting the argument that HPWS will only be applied and only generate positive outcomes among professionals in the manufacturing sector but less effective in the service sector. As Harley et al. (2007) state, we should challenge the argument that HPWS will not be widely applied in low-skilled jobs in the service sector organizations. In practical terms, Harley et al. (2007:623-624) suggest that "Workers can benefit from HPWS in the service sector. This is not to say that workers and unions should rush forth and embrace HPWS. Rather, it is to caution against the assumption that they should necessarily resist such practices." The challenge for researchers who wish to inform practice is to build on existing research and to identify the conditions under which HPWS is beneficial for workers. Thus, the empirical evidence concerning the applicability of HPWS in services remains far from conclusive. 


\section{References}

Appelbaum, E. and Batt, R. (1994), The new American workplace, Ithaca: ILR Press.

Appelbaum, E., Bailey, T., Berg, P. and Kalleberg, A. (2000), Manufacturing advantage: Why high-performance work systems pay off, Ithaca: ILR Press.

Appelbaum, E., Bernhardt, A., and Murnane, R.J. (2003), Low-wage America: How employers are reshaping opportunity in the workplace (1st ed.), New York: Russell Sage Foundation.

Bartel, A. (2004), Human resource management and organizational performance: Evidence from retail banking. Industrial and Labor Relations Review, Vol. 57, No. 2, pp. 181-203.

Bartram, T., Casimir, G. Djurkovic, N., Leggat, S.G., and Stanton, P. (2012), Do perceived high performance work systems influence the relationships between emotional labor, burnout and intention to leave? A study of Australian nurses, Journal of Advanced Nursing, Vol. 68, No. 7), pp. 1567-1578.

Bartram, T., Stanton, P., Leggat, S., Casimir, G., and Fraser, B. (2007), Lost in translation: exploring the link between HRM and performance in healthcare, Human Resource Management Journal, Vol. 17, No.1,pp. 21-41.

Batt, R. (2007), Service strategies marketing, operations, and human resource practices [Electronic version]. Retrieved July 16, 2019, from Cornell University, ILR School site: http://digitalcommons.ilr.cornell.edu/articles/943

Becker, B.E. and Huselid, M.A. (2006), Strategic human resource management: Where do we go from here? Journal of Management, Vol. 32, No. 6, pp. 898-925.

Berg, P. and Frost, A. (2005), Dignity at work for low wage, low skill service workers, Relations Industrielles/Industrial Relations, Vol. 60, No. 4, pp. 657-682.

Boxall, P. (2012), High- performance work systems: What, why, how and for whom? Asia Pacific Journal of Human Resources, Vol. 50, pp. 169-186.

Boxall, P. and Macky, K. (2007), High- performance work systems and organizational performance: Bridging theory and practice, Human Resource Management Journal, Vol. 19, No.1, pp. 3-23.

Boxall, P. and Macky, K. (2009), Research and theory on high- performance work systems: Progressing the high-involvement stream, Human Resource Management Journal, Vol.19, No.1, pp. 3-23.

Boxall,P. and Purcell,J. (2008),Strategy and human resource management (2nd ed.), New York: Palgrave Macmillan.

Chuang, C. and Liao, H. (2010), Strategic human resource management in service context: Taking care of business by taking care of employees and customers, Personnel Psychology, Vol. 63, pp. 153-196.

Cooray, V.K.M. and Dayarathna, N.W.K.D.K. (2017), Aligning high performance work systems with internal organizational context: Case studies from Sri Lankan IT companies, Sri Lankan Journal of Human Resource Management, Vol. 7, No.1, pp.35-58.

Datta, D.K., Guthrie, J.P., and Wright, P.M. (2005), Human resource management and labor productivity: Does industry matter? The Academy of Management Journal, Vol. 48, No.1, pp. 135-145. 
Dayarathna, N.W.K.D.K. (2012), Do high performance work systems pay off in Asia? Proceedings, Annual research sessions, International Conference on Business Management, Sri Lanka.

Dessler, G. (2009), Fundamentals of Human Resource Management: Content, Competencies, and Applications, New Jersey: Pearson Prentice Hall.

Guthrie, J.P., Flood, P.C., Liu, W., and MacCurtain, S. (2009), High performance work systems in Ireland: Human resource and organizational outcomes, The International Journal of Human Resource Management, Vol. 20, No.1,pp. 112-125.

Harley, B., Allen, B. C., and Sargent, L.D. (2007), High performance work systems and employee experience of work in the service sector: The case of aged care, British Journal of Industrial Relations, Vol. 45, No.3, pp. 607-633.

Huselid, M.A. (1995), The impact of human resource management practices on turnover, productivity and corporate financial performance, The Academy of Management Journal, Vol. 38, No. 3, pp. 635-672.

Iddhagoda and Opatha, (2018), The intensity of the implementation of high-performance work practices in selected Sri Lankan companies, Spoteczenstwo I Rodzina, Vol. 56, No.3, pp. 69-95.

Kuvaas, B. (2008), Does best HRM only work for intrinsically motivated employees?, Journal of Management Studies, Vol. 45, No.1, pp. 1-25.

Kuvaas, B. and Dysvik, A. (2010), Does best HRM only work for intrinsically motivated employees? The International Journal of Human Resource Management, Vol. 21, No.13, pp. 2339-2357.

Leana, C.R. and Van Buren, H.J. (1999), Organizational social capital and employment practices, The Academy of Management, Vol. 24, No.3, pp. 538-555.

Leggat, S.G., Bartram, T., and Stanton, P. (2011), High performance work systems: The gap between policy and practice in health care reform, Journal of Health Organization and Management, Vol. 25, No. 3, pp. 281-297.

Liao, H. Toya, K., Lepak, D.P., and Hong, Y. (2009), Do they see eye to eye? Management and employee perspectives of HPWS and influence processes on service quality, Journal of Applied Psychology, Vol. 94, No.2, pp. 371-391.

Macduffie, J.P. (1995), Human resource bundles and manufacturing performance: Organizational logic and flexible production systems in the world auto industry, Industrial and Labor Relations Review, Vol. 48, No. 2, pp. 197-221.

Macky, K., and Boxall, P. (2007), The relationship between high performance work practices and employee attitudes: An investigation of additive and interaction effects, The International Journal of Human Resource Management, Vol. 18, No.4, pp. 537-567.

McAlearney, A.S., Garman, A.N., Song, P.H., McHugh, M., Robbins, J., and Harrison, M.I. (2011), High performance work systems in health care management, part 2: Qualitative evidence from five case studies, Health Care Management Review, Vol. 36, No. 3, pp. 214-226.

Mcclean, E. and Collins, C.J. (2011), High-commitment HR practices, employee effort, and firm performance: Investigating the effects of HR practices across employee groups within professional services firms, Human Resource Management, Vol. 50, No.3, pp.341-363. 
Messersmith, J. G., Patel, P.C., and Lepak, D. P. (2011), Unlocking the black box: Exploring the link between high performance work systems and performance, Journal of Applied Psychology, Vol. 96, No.6, pp.1105-1118.

Nikandrou, I. and Papalexandris, N. (2007), The impact of $M$ and A experience on strategic HRM practices and organizational effectiveness: Evidence from Greek firms, Human Resource Management Journal, Vol.17, No.2,pp. 155-177.

O'neill, O.A., Feldman, D.C., Vandenberg, R.J., Dejoy, D.M., and Wilson, M.G. (2011), Organizational achievement values, high-involvement work practices, and business unit performance, Human Resource Management, Vol. 50, No.4,pp. 541-558.

Pfeffer,J. (1998), The real keys to high performance, Leader to Leader, Vol. 8, pp. 23-29.

Pine, B.J. (1993), Mass customization-The new frontier in business competition, Harvard Business School Press, Boston.

Preuss, G.A. (2003), HPWS and organizational outcomes: The mediating role of information quality, Industrial and Labour Relations Review, Vol. 56, No. 4, pp. 590-605.

Zacharatos, A., Barling, J. and Iverson, R.D. (2005), High performance work systems and occupational safety, Journal of Applied Psychology, Vol. 90, No.1, pp. 77- 93.

Zatzick, C.D. and Iverson, R.D. (2011), Putting employee involvement in context: A cross-level model examining job satisfaction and absenteeism in high-involvement work systems, The International Journal of Human Resource Management, Vol. 22, No.17, pp. 3462-3476. 